\title{
Effect of glycerol, n, n-dimethylformamide and n-methyl-2-pyrrolidone on rabbit sperm stored at $4{ }^{\circ} \mathrm{C}$ and $16^{\circ} \mathrm{C}$
}

\author{
Paula Domingo $^{1 *}$ (D), Maite Olaciregui ${ }^{1}$ (D), Noelia González ${ }^{1}$ (D), Ignacio De Blas ${ }^{2}$ (D), Lydia Gil ${ }^{1}$ \\ ${ }^{1}$ Universidad de Zaragoza, Facultad de Veterinaria, Área de Obstetricia y Reproducción Animal, Departamento de Patología \\ Animal, España \\ ${ }^{2}$ Universidad de Zaragoza, Facultad de Veterinaria, Área de Salud Animal, Departamento de Patología Animal, España
}

\begin{abstract}
Artificial insemination with cooled semen is the most common practice in rabbit farms and any improvement on it helps to increase the efficiency and productivity of rabbit meat farms. Therefore, the aim of this study was to assess whether different cryoprotectant agents (CPA) as glycerol, N, N-Dimethylformamide (DMF) and N-Methyl-2-Pyrrolidone (NMP) can improve cooled rabbit sperm quality stored at $4^{\circ} \mathrm{C}$ and $16^{\circ} \mathrm{C}$. Sperm samples were diluted with INRA $96^{\circledR}$ (Extender A), INRA $96{ }^{\circledR}$ with $6 \%$ glycerol (Extender B) or $6 \%$ DMF (Extender C) or 6\% NMP (Extender D) respectively and stored at $4^{\circ} \mathrm{C}$ and $16^{\circ} \mathrm{C}$. Samples were then analysed at 4, 24, 48 and 72 hours after refrigeration by integrated sperm analysis system $\left(\mathrm{ISAS}^{\circledR}\right)$, eosin-nigrosin stain (vitality), hypo-osmotic swelling test (HOS test) and acrosome integrity test. Extender $\mathrm{C}$ showed higher percentage of motility, vitality and HOS test than extender $\mathrm{B}$ and $\mathrm{D}(p<0.05)$. Whereas sperm quality decreased over time $(p<0.05)$, data showed that the addition of DMF kept the motility and sperm plasma membrane integrity after 24 hours of storage better than other diluents. These results suggest that the addition of DMF to INRA $96^{\circledR}$ exerts a protective effect on the membrane of spermatozoa improving seminal quality.
\end{abstract}

Keywords: cryoprotectant, dimethylformamide, n-methyl2-pyrrolidone, glycerol, rabbit sperm preservation.

\section{Introduction}

Spermatozoon survival is affected by storage temperature and extender (Carluccio et al., 2004). Currently, the most common temperature used to preserve rabbit sperm in farms is around $16{ }^{\circ} \mathrm{C}$ due to the fertility is considerably lower after 48 hours of storage (López and Alvariño, 1998; Roca et al., 2000; Rosato et al., 2006; Johinke et al., 2014). Likewise, the extender affects sperm quality. Many extenders (López and Alvariño, 2000; Carluccio et al., 2004) and substances (Trejo et al., 2013; Johinke et al., 2014; Sarı̈zkan et al., 2014) have been evaluated in order to preserve semen the most time possible for carry it to another farms. Nevertheless, Carluccio et al. (2004) demonstrated that INRA $96^{\circledR}$ kept rabbit sperm quality better than others

*Correspondence: paula.domingo.tomas@gmail.com

Received: August 9, 2018

Accepted: August 2, 2019 extenders even though INRA $96^{\circledR}$ was made specifically for the preservation of stallion sperm.

Moreover, because of rabbit sperm characteristics (high activation energy and low water permeability coefficient), cryoprotectant agents (CPA) with lower molecular weight and higher permeability, such as amides or methyl groups, are suitable to be used (Curry et al., 1995; Mocé and Vicente, 2009). N, N-Dimethylformamide (DMF) is an amide solvent used in chemical reactions. Previous studies in boar (Malo et al., 2012), canine (Futino et al., 2010; Lopes et al., 2009; Mota et al., 2011), goat (Bezerra et al., 2011) and fowl sperm (Chalah et al., 1999) demonstrated that DMF is not better CPA than glycerol. However, stallion sperm (Alvarenga et al., 2005; Olaciregui et al., 2014; Pukazhenthi et al., 2014) diluted with DMF as an alternative to glycerol showed better results. N-Methyl-2-Pyrrolidone (NMP) is also an amide solvent commonly used in chemical reactions as an alternative to DMF. But unlike DMF, NMP has not been studied before for storage sperm samples.

On the other hand, glycerol is the main CPA used to preserve domestic or wild animal sperm (Curry et al., 1995). Nevertheless, glycerol has not been the first CPA of choice to preserve rabbit semen due to its toxicity, which may result in osmotic stress, protein denaturation, alteration of actin interactions and induction of protein-free membrane blister that leads to get worse fertility (Alvariño, 1993; Gilmore et al., 1995; Okuda et al., 2007; Iaffaldano et al., 2012).

The lack of previous studies using DMF or NMP as a CPA in rabbit sperm preservation and the supposed toxicity of glycerol, leads to study more these CPA. The aim of this study was to assess the quality of cooled rabbit sperm stored at $4{ }^{\circ} \mathrm{C}$ and $16^{\circ} \mathrm{C}$ and diluted with INRA $96^{\circledR}$ supplemented with glycerol, DMF or NMP. Moreover, evaluate the effect of storage time during 72 hours and decide whether glycerol, DMF or NMP can be used as CPA on cooled rabbit semen preservation.

\section{Methods}

\section{Chemicals}

Unless noted otherwise, all chemicals were from Panreac Quimica S.L.U (Barcelona, Spain). 
Animals, semen collection and processing

The study was performed following approval by the Veterinary Ethical Committee of University of Zaragoza. The care and use of animals were performed according to the Spanish Policy for Animal Protection RD1201/05, which meets the European Union Directive 86/609 on the protection of animals used for experimental and other scientific purposes.

Rabbit sperm samples were collected from eight sexually mature bucks previously selected from a commercial AI centre (Técnicas Cunícolas S.A., Zaragoza, Spain) and used as semen donors. Males were housed in individual cages with 12 hours of light and 12 hours of darkness at a room temperature of $22-24{ }^{\circ} \mathrm{C}$ and a relative humidity of $60-70 \%$. All rabbits were fed a commercial pellet diet according to their reproductive condition and fresh water was provided ad libitum.

Rabbit sperm samples were collected using artificial vagina (IMV Technologies, L'Aigle, France). After semen collection, any gel plug was removed and a macroscopic analysis was performed assessing the colour and the volume of the sample. The first microscopic analysis of the motility in the farm was made as well. Only ejaculates with white colour, more than $0,2 \mathrm{ml}$ and good wave motion (at least $85 \%$ of motility) were used for the research.

All ejaculates were pooled with the purpose of eliminate individual differences, thereafter were divided in four fractions and each one was diluted with a different extender: INRA $96^{\circledR}$ (IMV Technologies, L'Aigle, France) (Extender A) as control, and INRA $96^{\circledR}$ supplemented with $6 \%$ glycerol (Extender B), 6\% DMF (Extender C) or 6\% NMP (Extender D).

Subsequently, each semen sample was placed into two Eppendorf tube in order to store each sample at $4{ }^{\circ} \mathrm{C}$ and at $16{ }^{\circ} \mathrm{C}$. Samples were cooled progressively from $37{ }^{\circ} \mathrm{C}$ to $16{ }^{\circ} \mathrm{C}$ and $4{ }^{\circ} \mathrm{C}$ in a time period among 90 and 120 minutes (Mocé and Vicente, 2009) and finally they were stored.

\section{Evaluation of spermatozoa}

Sperm motility, vitality, membrane integrity and acrosome integrity were assessed at 4, 24, 48 and 72 hours after collection for both temperature storage and all extenders.

\section{Sperm motility and kinematics}

Sperm motility and kinematics parameters were evaluated by ISAS ${ }^{\circledR}$ software (PROISER R+D, Valencia, Spain) following the default setting specifically for rabbits. Five microliters were placed on a slide and covered with $20 \times 20 \mathrm{~mm}$ coverslip. Five fñields were randomly captured at $\times 10$ magnification by phase-contrast microscope. Up to 200 frames per second were acquired selecting particles with an area of between 10 and $70 \mu \mathrm{m}^{2}$. The cut-off values used to determine sperm velocity were $10<$ slow $<25<$ medium $<50<$ rapid $(\mu \mathrm{m} / \mathrm{s})$. The linearly motile sperm were deviated $<45 \%$ from a straight line. The analyses provided information about the percentage of motile spermatozoa (MOT, \%), curvilinear velocity $(\mathrm{VCL}, \mu \mathrm{m} / \mathrm{s})$, straight-line velocity (VSL, $\mu \mathrm{m} / \mathrm{s}$ ), average path velocity (VAP, $\mu \mathrm{m} / \mathrm{s}$ ), linearity (LIN=VSL/VCL, \%), straightness (STR=VSL/VAP, \%), wobble (WOB=VAP/VCL, \%), amplitude of lateral head displacement $(\mathrm{ALH}, \mu \mathrm{m})$ and beat cross frequency (BCF, Hz).

Vitality

Eosin-nigrosin stain was used to evaluate the vitality of the spermatozoa following the protocol described by Björndahl et al. (2003). According to the stain penetration trough the damaged membrane the dead spermatozoa had red or dark pink heads (stained) and the live spermatozoa had white heads (unstained) (WHO, 2010).

Sperm plasma membrane integrity

Hypo-osmotic swelling test (HOS test) was performed following the protocol established by Jeyendran et al. (1984). Ten microliters of semen were mixed with $90 \mu 1$ of HOS test solution (100 mM of Sodium Citrate) and kept at $37{ }^{\circ} \mathrm{C}$ at least 30 minutes. Subsequently $100 \mu \mathrm{l}$ of glutaraldehyde $2 \%$ was added to the sample for fix it. Each sample was analysed by phase-contrast microscope at x400 magnification. Spermatozoa with intact membranes allowed an influx of water inside the cell giving place to swollen spermatozoa with coiling tail (Amorim et al., 2009; WHO, 2010).

\section{Acrosome integrity}

Acrosome integrity test is based on the fixation of the spermatozoa. Ten microliters of semen was immediately fixed in $90 \mu \mathrm{l}$ of glutaraldehyde $2 \%$ solution, right after each sample was analysed by phase-contrast microscope at x 1000 magnification (Pursel and Johnson, 1974). Acrosomes were differentially categorized into two classes: intact acrosome (normal apical ridge) and damaged acrosome (damaged apical ridge and/or missing apical ridge).

\section{Statistical analysis}

The study was replicated three times. Data were analysed using IBM SPSS Statistics 23 for Windows. Results were expressed as mean \pm SEM. The effect of the extender, storage temperature and time of storage on the studied parameters were analysed by ANOVA. Duncan's post-hoc test was used to evaluate the effect of the extender and time of storage. The interactions among the extender used, storage temperature and time elapsed were assessed using GLM procedure. The level of significance was set at $p<0.05$.

\section{Results}

The effect of the extender played an important role in seminal preservation, in fact, all parameters studied 
were significantly significant $(p<0.05)$, excluding acrosome integrity parameter (Table 1 and Figure 1). When the samples were diluted with extender $\mathrm{C}$, the data obtained were similar to control samples (extender A), moreover extender $\mathrm{C}$ got higher percentage $(p<0.05)$ of MOT, vitality and HOS test. A few worse results of MOT, vitality and HOS test were obtained by extender D, though the worst results were observed in samples diluted with extender B. Other kinematic parameters were studied, showing extender A greater results on velocity and trajectory.

When the effect of storage temperature on cooled rabbit sperm was analysed no significant differences were observed on MOT, kinematic parameters, vitality, HOS test and acrosome integrity. With the exception of BCF parameter $(p<0.001)$, which was higher when sperm samples were stored at $4{ }^{\circ} \mathrm{C}(8.307 \pm 0.189 \mathrm{~Hz})$ instead of $16^{\circ} \mathrm{C}$ $(7.475 \pm 0.203 \mathrm{~Hz})$. In spite of no statistically differences were observed between storage samples at $4{ }^{\circ} \mathrm{C}$ or $16^{\circ} \mathrm{C}$, it should be noted that studying thoroughly the interaction between the diluents and the temperature statistically differences $(p=0.027)$ on MOT were shown (Figure 2).
Regarding all sperm parameters studied, sperm quality decreased over storage time $(p<0.05)$ (Table 2$)$. The percentage of total sperm motility dropped off from $64.7 \pm 2.3 \%$ at 4 hours after collection to $44.5 \pm 2.3 \%$ passing 48 hours. Nevertheless, the sharpest decline of motility was from 72 hours of storage $(28.6 \pm 2.6 \%$ of motile spermatozoa). The vitality of spermatozoa was kept till 72 hours after storage, from $87.5 \pm 1.8 \%$ to $75.3 \pm 1.7 \%$ of live spermatozoa. Almost all kinematic parameters and acrosome integrity shown a considerable decline after 24 hours of storage. Lastly, sperm plasma membrane was started to damage as of 48 hours.

The interaction between the extender and the hours that elapsed since the collection of the samples are presented in Figure 3. All the parameters studied, except acrosome integrity, were statistically significant $(p<0.05)$ showing that as time goes by, semen quality decreases.

Extender A obtained the highest MOT up to 24 hours, but after that period of time the addition of DMF to INRA $96^{\circledR}$ offered higher MOT. Extender C obtained the best data on MOT at 72 hours $(40.8 \pm 4.6 \%)$. MOT parameter was similar for extender C and D until 24 hours

Table 1. Effect of the extender on kinematic parameters determined by ISAS. Different letters within each column indicate statistically significant differences $(p<0.05)$. Data are mean \pm SEM.

\begin{tabular}{|c|c|c|c|c|c|c|c|c|c|}
\hline & $\begin{array}{c}\text { MOT } \\
\mathbf{( \% )} \\
\end{array}$ & $\begin{array}{c}\text { VCL } \\
(\mu \mathrm{m} / \mathbf{s})\end{array}$ & $\begin{array}{c}\mathrm{VSL} \\
(\mu \mathrm{m} / \mathrm{s})\end{array}$ & $\begin{array}{c}\text { VAP } \\
(\mu \mathrm{m} / \mathbf{s})\end{array}$ & $\begin{array}{l}\text { LIN } \\
(\%) \\
\end{array}$ & $\begin{array}{l}\text { STR } \\
\mathbf{( \% )} \\
\end{array}$ & $\begin{array}{c}\text { WOB } \\
\mathbf{( \% )} \\
\end{array}$ & $\begin{array}{l}\text { ALH } \\
(\mu \mathrm{m})\end{array}$ & $\begin{array}{l}\text { BCF } \\
\mathbf{( H z )}\end{array}$ \\
\hline Ex & $.9 \pm 2.4$ & $3.7 \pm 2.4^{\mathrm{ab}}$ & $26.7 \pm 1.1^{\mathrm{a}}$ & $3.9 \pm 1.4^{\mathrm{a}}$ & $35.1 \pm 1.1^{\mathrm{a}}$ & $59.1 \pm 1.0^{\mathrm{bc}}$ & $58.1 \pm 1.0^{\mathrm{a}}$ & $2.9 \pm 0.1^{b}$ & $7.3 \pm 0.3^{b}$ \\
\hline Ext & $35.4 \pm 2.4^{\mathrm{c}}$ & $66.9 \pm 2.3^{b}$ & $22.1 \pm 1$ & $1 \pm$ & $34.9 \pm$ & $61.1 \pm 1$ & $55.9 \pm$ & $3.1 \pm$ & $7.6 \pm$ \\
\hline $\mathrm{C}$ & $59.3 \pm 2.2^{\mathrm{a}}$ & $75.5 \pm 2.3^{\mathrm{a}}$ & $21.5 \pm 1.1^{\mathrm{bc}}$ & $37.2 \pm 1.3^{\mathrm{b}}$ & $29.5 \pm 1.0^{b}$ & $58.0 \pm$ & $50.3 \pm 1.0^{b}$ & $3.4 \pm$ & $8.4 \pm 0.3^{\mathrm{a}}$ \\
\hline Ex & $47.5 \pm 2.2^{b}$ & $56.7 \pm 2.3^{\mathrm{c}}$ & $3.9 \pm 1.1^{\mathrm{c}}$ & $28.3 \pm 1.3^{c}$ & $3.9 \pm 1.0^{\mathrm{a}}$ & $65.9 \pm 1.0^{\mathrm{a}}$ & $1.5 \pm 1.0^{b}$ & $3.0 \pm 0.1^{\mathrm{b}}$ & $3 \pm 0.3^{\mathrm{a}}$ \\
\hline . & 0.001 & 0.001 & 0.001 & 0.001 & 0.001 & 0.001 & 0.001 & 0.001 & 0.001 \\
\hline
\end{tabular}

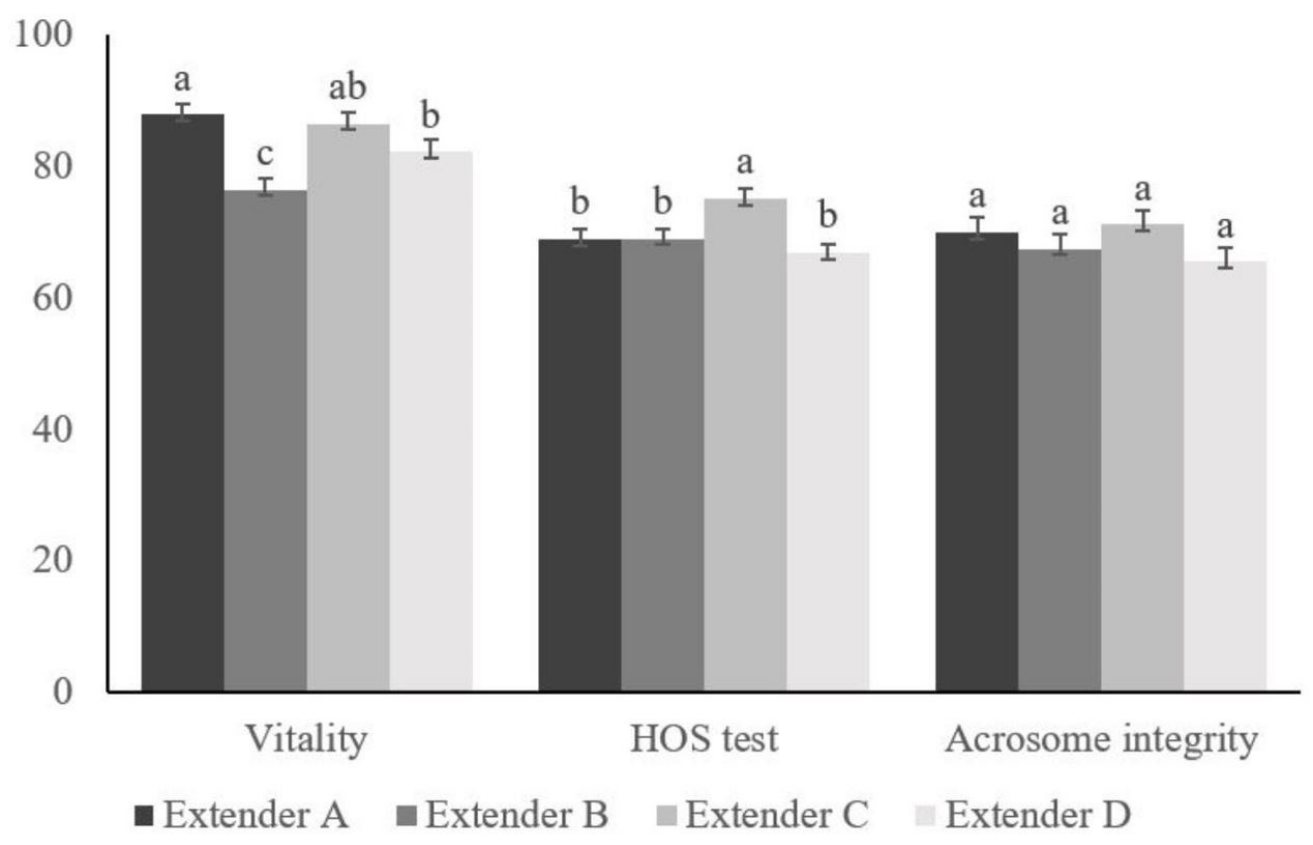

Figure 1. Percentage of vitality, HOS test and acrosome integrity of rabbit spermatozoa diluted with extender A, extender B, extender $\mathrm{C}$ and extender $\mathrm{D}$ from the $16{ }^{\circ} \mathrm{C}$ and $4{ }^{\circ} \mathrm{C}$ groups. Data are mean $\pm \mathrm{SEM}$. Different letters within each diagnostic test denote statistical differences $(\mathrm{p}<0.05)$. 


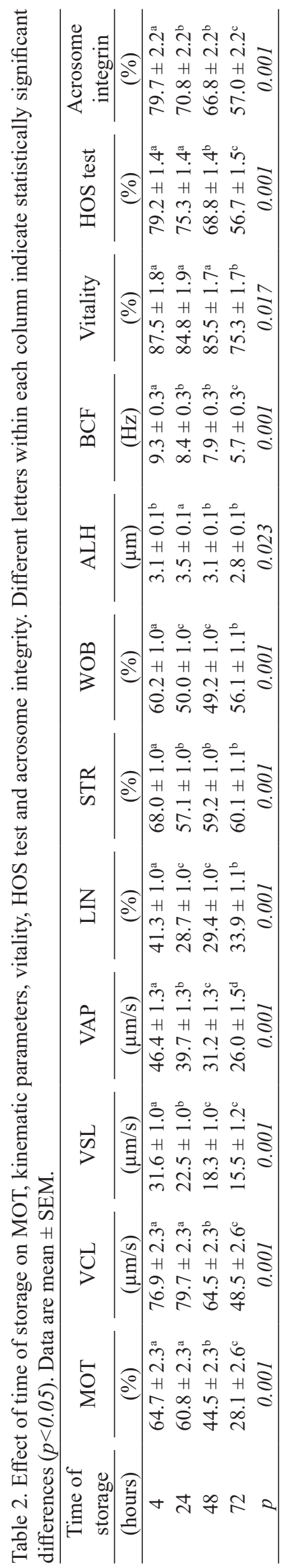


of storage, thereafter MOT dropped reaching less than 20\% at 72 hours after collection. Extender B obtained the worst MOT in relation to other extenders $(p<0.05)$ (Figure $3 a)$.

The percentage of alive spermatozoa obtained with extender A was similar than extender $\mathrm{C}$ during 72 hours (Figure $3 \mathrm{~b}$ ). Extender B or D showed similar values till 48 hours of storage, after 48 hours of storage the vitality of spermatozoa diluted with extender B came down from $82.6 \pm 3.5 \%$ at 48 hours to $56.9 \pm 3.5 \%$ at 72 hours of storage $(p<0.05)$.

The evaluation of the damage of the sperm plasma membrane is synthesise in Figure 3c. As it is shown, extender $\mathrm{C}$ offered better protection on the sperm plasma

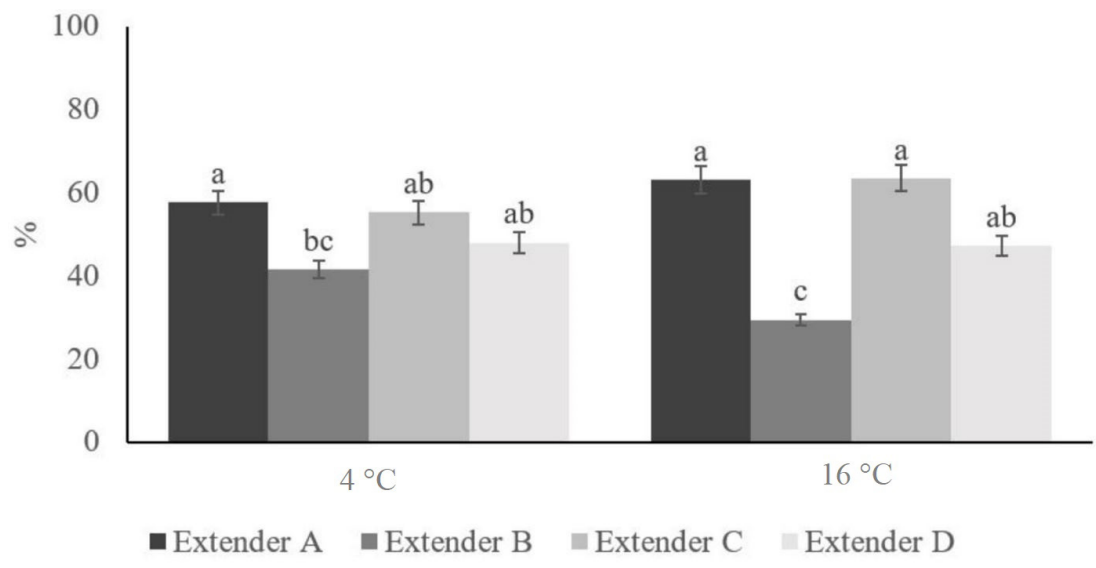

Figure 2. Effect of the temperature on the motility parameter of rabbit spermatozoa diluted with extender A, extender B, extender $C$ and extender D. Data are mean \pm SEM. Different letters within each diagnostic test denote statistical differences $(\mathrm{p}<0.05)$.
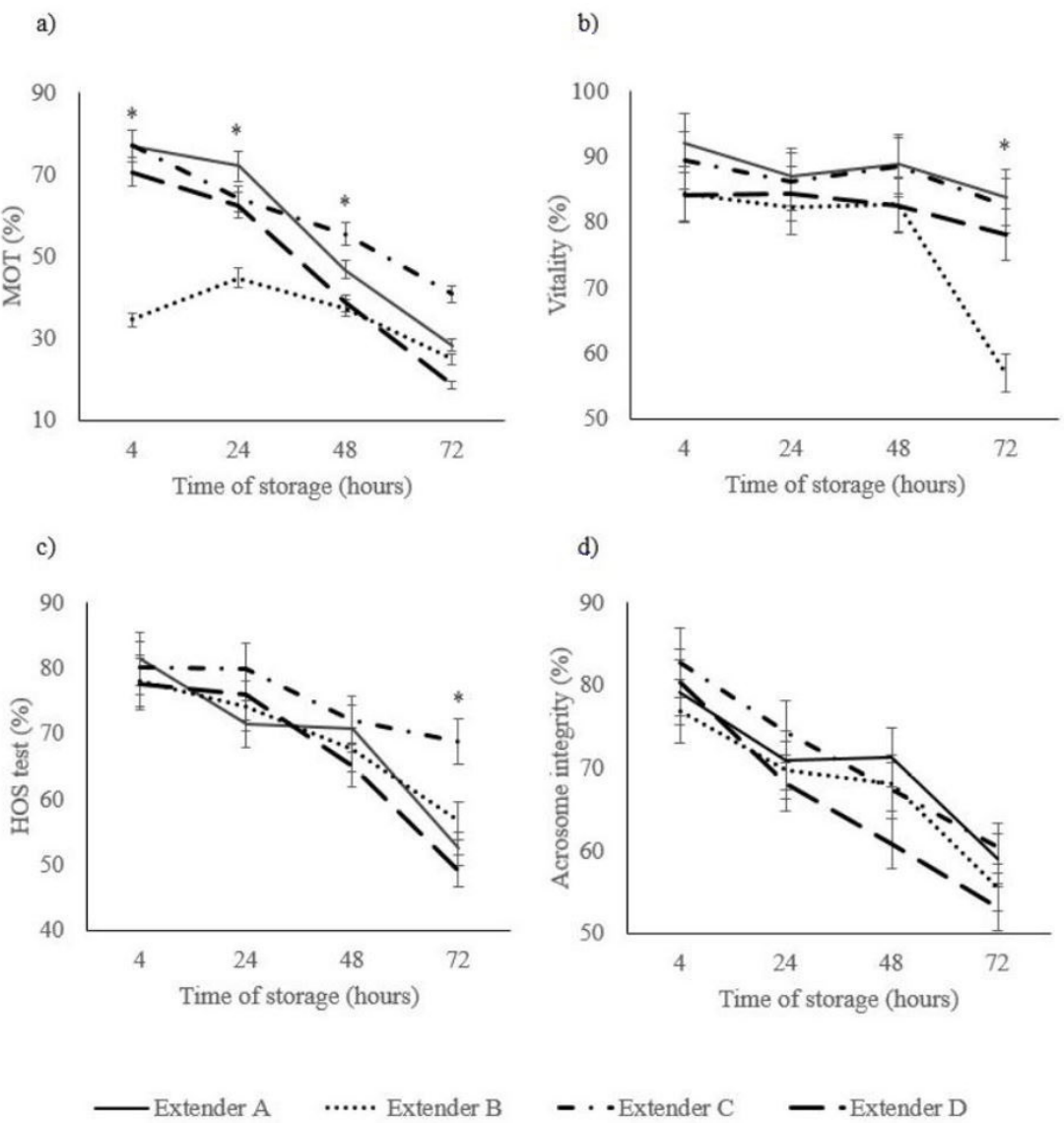

$$
\text { - - Extender C - Extender D }
$$

Figure 3. Percentage of MOT, vitality, HOS test and acrosome integrity of rabbit spermatozoa at 4, 24, 48, and 72 hours from the four extender (A-D) groups. Data are mean \pm SEM. Means marked with an asterisk within each time point denote statistical differences $(\mathrm{p}<0.05)$. 
membrane, observing statistically differences $(p<0.05)$ after 72 hours of storage.

\section{Discussion}

It is known that the addition of CPA to an extender is performed with the goal of protect the sperm from cryodamage, which causes devastating consequences in sperm survival during sperm cooling process. Though also, CPA, such as glycerol, could have a toxic effect on sperm (membrane destabilization, protein and enzyme denaturation, osmotic stress, alteration of actin interactions and induction of protein-free membrane blister) directly related to the concentration used and the time of cell exposure (Alvariño, 1993; Gilmore et al., 1995; Okuda et al., 2007; Iaffaldano et al., 2012). Interestingly, this study on rabbit sperm showed same results as previous studies in stallion sperm preservation (Olaciregui et al., 2014; Pukazhenthi et al., 2014): the addition of DMF maintained cooled rabbit sperm quality better than glycerol. In addition, samples diluted with INRA $96^{\circledR}$ plus DMF got, along with samples diluted with INRA $96^{\circledR}$, the best sperm quality during cooled sperm preservation. Surprisingly, sperm quality decreased when samples were diluted with INRA $96^{\circledR}$ plus NMP. Reminding of rabbit sperm characteristics, the most appropriate solvents to use in rabbit sperm preservation should have low molecular weight and high permeability, such as amides (Curry et al., 1995; Mocé and Vicente, 2009). Therefore, the differences found between DMF and NMP could be owing to their molecular weights and densities. Despite DMF and NMP are both an amide solvents, NMP has higher molecular weight $(99.13 \mathrm{~g} / \mathrm{mol})$ and density $\left(1.028 \mathrm{~g} / \mathrm{cm}^{3}\right)$ than DMF $\left(73.09 \mathrm{~g} / \mathrm{mol}\right.$ of molecular weight; $0.944 \mathrm{~g} / \mathrm{cm}^{3}$ of density). These small differences in their composition might suggest that are responsible for NMP not being a good CPA for storage cooled rabbit sperm. Anyhow, further studies should be carried out to determine the optimal concentration of NMP.

On the other hand, as expected glycerol got the worst data due to its toxicity previously demonstrated by other authors (Alvariño, 1993; Gilmore et al., 1995; Okuda et al., 2007), not getting nor $30 \%$ of motile rabbit sperm storing it at $16^{\circ} \mathrm{C}$.

Previous studies have shown the ability of rabbit sperm to resist environmental stress. Because of the droplets and vesicles present in rabbit sperm; they are rich in cholesterol and phospholipids, assisting to modulate the membrane fluidity and in this way to withstand greater cold shock (Sparr et al., 2002; Castellini et al., 2006; Mocé and Vicente, 2009). Moreover, the high cholesterol:phospholipid ratio of rabbit sperm plasma membrane allows the ability to fertilize oocytes from cooling sperm at $4{ }^{\circ} \mathrm{C}$ is similar to fresh sperm (Mocé and Vicente, 2009). In the present study on cooled rabbit sperm, we demonstrated that there are no differences between storage rabbit sperm at $4{ }^{\circ} \mathrm{C}$ or $16^{\circ} \mathrm{C}$ when INRA $96^{\circledR}$ is the extender used, contrarily other study published by Johinke et al. (2014) which using Tris-citric-acid extender with two different concentrations of glucose, obtained better results when stored rabbit sperm at $15^{\circ} \mathrm{C}$ instead of $5^{\circ} \mathrm{C}$. Considering this, we can appreciate that the extender and CPA play an important role, moreover INRA $96^{\circledR}$ extender can be used satisfactorily among $4{ }^{\circ} \mathrm{C}$ and $16^{\circ} \mathrm{C}$.

As expected, in this study the sperm quality of all the samples decreased throughout storage time as other authors previously reported (López and Alvariño, 1998; Roca et al., 2000), showing after 48 hours a considerable drop on MOT parameter. Nevertheless previous studies demonstrated that MOT is not the only good parameter to evaluate sperm quality, other parameters related with MOT such as VCL, VSL, VAP, LIN, STR, WOB, ALH and BCF are also useful to predict male in vitro fertility (Liu et al., 1991; Hagen et al., 2010). To date, all kinematic parameters in rabbit spermatozoa have never been studied previously by other authors. Surprisingly, in this study we can appreciate that almost all kinematic parameters only were maintained till 24 hours, unlike vitality parameter which hardly showed a decline during 72 hours of storage. Moreover, even though the quality of all the samples decreased throughout storage time, data showed that the addition of DMF kept the motility and sperm plasma membrane integrity after 24 hours of storage better than other extenders.

Summarising, these results demonstrated that the addition of DMF to INRA $96^{\circledR}$ diluent exerts a protective effect on the membrane of spermatozoa and therefore it improve seminal quality. Moreover NMP could not be used to replace DMF considering that worse results were obtained. Also we are in agreement with previous results reported for the toxicity of glycerol, which made it not a good cryoprotector (Alvariño, 1993; Gilmore et al., 1995; Okuda et al., 2007). Finally, the temperature of storage among $4{ }^{\circ} \mathrm{C}$ and $16{ }^{\circ} \mathrm{C}$ did not affect the quality of rabbit sperm diluted with INRA $96^{\circledR}$.

\section{Acknowledgements}

The authors would like to thank Miguel Domingo, chief of Técnicas Cunicolas S.A. farm, for his incalculable help in the fieldwork. This study was supported by Government of Aragon Research Groups (Fondo Social Europeo, DGA) and IA2.

\section{REFERENCES}

Alvarenga MA, Papa FO, Landim-Alvarenga FC, Medeiros ASL. Amides as cryoprotectants for freezing stallion semen: A review. Anim Reprod Sci. 2005;89(1-4):10513. http://dx.doi.org/10.1016/j.anireprosci.2005.07.001. PMid:16099609.

Alvariño MR. Control de la reproducción del conejo. Madrid: Ed. Mundi-Prensa; 1993.

Amorim EAM, Torres CCA, Graham JK, Amorim LS, Santos LVL. The hypoosmotic swelling test in fresh rabbit spermatozoa. Anim Reprod Sci. 2009;111(2-4):338-43. http://dx.doi.org/10.1016/j.anireprosci.2008.02.015. PMid:18583071. 
Bezerra FSB, Castelo TS, Alves HM, Oliveira IRS, Lima GL, Peixoto GCX, Bezerra ACSD, Silva AR. Objective assessment of the cryoprotective effects of dimethylformamide for freezing goat semen. Cryobiology. 2011;63(3):263-6. http:// dx.doi.org/10.1016/j.cryobiol.2011.09.136. PMid:21985769.

Björndahl L, Soderlund I, Kvist U. Evaluation of the one step eosin-nigrosin staining technique for human sperm vitality assessment. Hum Reprod. 2003;18(4):813-6. http:// dx.doi.org/10.1093/humrep/deg199. PMid:12660276.

Carluccio A, Robbe D, Amicis I, Contri A, Tosi U, Russo F, Paoletti M. Artificial insemination in rabbits: laboratory and field trial with three different semen extenders. World Rabbit Sci. 2004;12:65-79.

Castellini C, Cardinali R, Dal Bosco A, Minelli A, Camici O. Lipid composition of the main fractions of rabbit semen. Theriogenology. 2006;65(4):703-12. http://dx.doi. org/10.1016/j.theriogenology.2005.05.053. PMid:16029885.

Chalah T, Seigneurin F, Blesbois E, Brillard JP. In Vitro comparison of fowl sperm viability in ejaculates frozen by three different techniques and relationship with subsequent fertility in vivo. Cryobiology. 1999;39(2):185-91. http:// dx.doi.org/10.1006/cryo.1999.2201. PMid:10529312.

Curry MR, Redding BJ, Watson PF. Determination of water permeability coefficient and its activation energy for Rabbit spermatozoa. Cryobiology. 1995;32(2):175-81. http://dx.doi.org/10.1006/cryo.1995.1016. PMid:7743819.

Futino DO, Mendes MCB, Matos WNL, Mondadori RG, Lucci CM. Glycerol, Methyl-Formamide and DimethylFormamide in canine semen cryopreservation. Reprod Domest Anim. 2010;45(2):214-20. http://dx.doi.org/10.1111/j.14390531.2008.01208.x. PMid:19019075.

Gilmore JA, McGann LE, Liu J, Gao DY, Peter AT, Kleinhans FW, Critser JK. Effect of cryoprotectant solutes on water permeability of human spermatozoa. Biol Reprod. 1995;53(5):985-95. http://dx.doi.org/10.1095/ biolreprod53.5.985. PMid:8527530.

Hagen DR, Gilkey AL, Foote RH. Spermatozoa velocity and motility and its relationship to fertility in the rabbit inseminated with low sperm numbers. World Rabbit Sci. 2010;10:135-40. http://dx.doi.org/10.4995/wrs.2002.485.

Iaffaldano N, Di Iorio M, Rosato MP. The cryoprotectant used, its concentration, and the equilibration time are critical for the successful cryopreservation of Rabbit sperm: dimethylacetamide versus dimethylsulfoxide. Theriogenology. 2012;78(6):1381-9. http://dx.doi.org/10.1016/j. theriogenology.2012.06.009. PMid:22898020.

Jeyendran RS, Van der Ven HH, Perez-Pelaez M, Crabo BG, Zaneveld LJ. Development of an assay to assess the functional integrity of the human sperm membrane and its relationship to other semen characteristics. J Reprod Fertil. 1984;70(1):219-28. http://dx.doi.org/10.1530/jrf.0.0700219. PMid:6694140.
Johinke D, Graaf SP, Bathgate R. Investigation of in vitro parameters and in vivo fertility of rabbit spermatozoa after chilled storage. Anim Reprod Sci. 2014;147(3-4):13543. http://dx.doi.org/10.1016/j.anireprosci.2014.04.014. PMid:24852269.

Liu DY, Clarke GN, Baker HWG. Relationship between spermmotility assessed with the Hamilton-Thorne motility analyzer andfertilization rates in vitro. J Androl. 1991;12(4):231-9. PMid:1917688.

Lopes KRF, Costa LLM, Lima GL, Souza ALP, Silva AR. Dimethylformamide is no better than glycerol for cryopreservation of canine semen. Theriogenology. 2009;72(5):650-4. http://dx.doi.org/10.1016/j. theriogenology.2009.04.021. PMid:19541362.

López FJ, Alvariño JMR. Artificial insemination of rabbits with diluted semen stored up to 96 hours. World Rabbit Sci. 1998;6:251-3.

López FJ, Alvariño JMR. Effects of added caffeine on results following artificial insemination with fresh and refrigerated rabbit semen. Anim Reprod Sci. 2000;58(12):147-54. http://dx.doi.org/10.1016/S0378-4320(99)000846. PMid:10700652.

Malo C, Gil L, Cano R, Martínez F, García A, Jerez RA. Dimethylformamide is not better that glycerol for cryopreservation of boar semen. Andrologia. 2012;44(Suppl 1):605-10. http://dx.doi.org/10.1111/j.1439-0272.2011.01237.x. PMid:21988610.

Mocé E, Vicente JS. Rabbit sperm cryopreservation: a review. Anim Reprod Sci. 2009;110(1-2):1-24. http://dx.doi. org/10.1016/j.anireprosci.2008.08.015. PMid:18805659.

Mota AC Fo., Teles CH, Jucá RP, Cardoso JF, Uchoa DC, Campello CC, Silva AR, Silva LD. Dimethylformamide as a cryoprotectant for canine semen diluted and frozen in ACP-106C. Theriogenology. 2011;76(7):1367-72. http://dx.doi.org/10.1016/j.theriogenology.2011.05.010. PMid:21719085.

Okuda Y, Seita Y, Hisamatsu S, Sonoki S, Shino M, Masaoka T, Inomata T, Kamijo S, Kashiwazaki N. Fertility of spermatozoa cryopreserved with $2 \%$ acetamide or glycerol through artificial insemination in the Japanese white rabbit. Exp Anim. 2007;56(1):29-34. http://dx.doi.org/10.1538/ expanim.56.29. PMid:17283888.

Olaciregui M, Gil L, Montón A, Luño V, Jerez RA, Martí JI. Cryopreservation of epididymal stallion sperm. Cryobiology. 2014;68(1):91-5. http://dx.doi.org/10.1016/j. cryobiol.2013.12.009. PMid:24412395.

Pukazhenthi BS, Johnson A, Guthrie HD, Songsasen N, Padilla LR, Wolfe BA, Silva MC, Alvarenga MA, Wildt DE. Improved sperm cryosurvival in diluents containing amides versus glycerol in the Przewalski's horse (Equus ferus przewalskii). Cryobiology. 2014;68(2):205-14. http://dx.doi.org/10.1016/j.cryobiol.2014.01.013. PMid:24508651. 
Pursel VG, Johnson L. Glutaraldehyde fixation of boar spermatozoa for acrosome evaluation. Theriogenology. 1974;1(2):63-8. http://dx.doi.org/10.1016/0093691X(74)90008-9. PMid:4219847.

Roca J, Martínez S, Vázquez JM, Lucas X, Parrilla I, Martínez EA. V Viability and fertility of rabbit spermatozoa diluted in Tris-buffer extenders and stored at $15^{\circ} \mathrm{C}$. Anim Reprod Sci. 2000;64(1-2):103-12. http://dx.doi.org/10.1016/ S0378-4320(00)00185-8. PMid:11078971.

Rosato MP, Rebollar PG, Iaffaldano N. Comparación de diferentes diluyentes en las características cualitativas del semen de conejo durante su conservación. In: Abstracts of the XXXI Simposium de Cunicultura; 2006; Lorca, España. Lorca: ASESCU; 2006. p. 9-13.

Sarı̈zkan S, Özdamar S, Türk G, Cantürk F, Yay A. In vitro effects of L-carnitine and glutamine on motility, acrosomal abnormality, and plasma membrane integrity of rabbit sperm during liquid-storage. Cryobiology. 2014;68(3):349-53. http:// dx.doi.org/10.1016/j.cryobiol.2014.04.006. PMid:24759298.

Sparr E, Hallin L, Markova N, Wennerström H. Phospholipidcholesterol bilayers under osmotic stress. Biophys J. 2002;83(4):2015-25. http://dx.doi.org/10.1016/S00063495(02)73963-5. PMid:12324420.

Trejo CA, Meza VVM, Antonio EC, Cotera RJ, AntonioCisneros CM. Coconut water (Cocus Nucifera) as a diluent for rabbit fresh semen in artificial insemination. Arch Zootec. 2013;62:299-302. http://dx.doi.org/10.4321/ S0004-05922013000200017.

WHO. Laboratory manual for the examination and processing of human semen. 5th Ed. Geneva: World Health Organization; 2010. p. 26-32.

\title{
Financial support: None.
}

Author contributions: PD: Writing - original draft, Data curation, Formal analysis, Methodology, and Conceptualization, MO: Review and editing; NG: Review and editing; IB: Data curation and Formal analysis; LG: Conceptualization, Supervision, Review and editing.

Conflicts of interest: The authors have no conflict of interest to declare.

\author{
Abbreviations \\ CPA: Cryoprotectant agents \\ DMF: N, N-Dimethylformamide \\ NMP: N-Methyl-2-Pyrrolidone \\ AI: Artificial insemination \\ MOT: Percentage of motile spermatozoa \\ VCL: Curvilinear velocity \\ VSL: Straight-line velocity \\ VAP: Average path velocity \\ LIN: Linearity \\ STR: Straightness \\ WOB: Wobble \\ ALH: Amplitude of lateral head displacement \\ BCF: Beat cross frequency \\ HOS test: Hypo-osmotic swelling test
}

